\title{
ANTIMICROBIAL ACTIVITY OF MINERAL TRIOXIDE AGGREGATE AND CALCIUM HYDROXIDE SEALER ON ENTEROCOCCUS FAECALIS STRAIN ATCC29212
}

\author{
TARA PRATHITA, NILA KESUMA DJAUHARIE*, RATNA MEIDYAWATI
}

Department of Conservative Dentistry, Faculty of Dentistry, Universitas Indonesia, Jakarta, Indonesia. Email: nila.setyopurnomo@gmail.com Received: 27 August 2018, Revised and Accepted: 07 February 2019

ABSTRACT

Objective: The objective of this study was to evaluate the antimicrobial activity of mineral trioxide aggregate (MTA) and calcium hydroxide (Ca(OH) sealers on Enterococcus faecalis at various time points after the preparation of the sealer.

Methods: Antimicrobial activity of MTA and $\mathrm{Ca}(\mathrm{OH})_{2}$ sealer on E. faecalis (ATCC 29212) was assessed by the direct contact test immediately, 1 day, and 7 days after the preparation of the sealer.

Results: The antimicrobial effect of MTA sealer was greatest 1 and 7 days after the preparation of the sealer. The effect of $\mathrm{Ca}(\mathrm{OH})_{2}$ was greatest 1 day after the preparation of the sealer.

Conclusion: MTA sealer showed constant antimicrobial activity on E. faecalis overtime. By contrast, $\mathrm{Ca}(\mathrm{OH})_{2}$ sealer showed decreasing antimicrobial activity overtime, with the greatest antimicrobial activity being 1 day after the preparation of the sealer.

Keywords: Antimicrobial activity, Calcium hydroxide sealer, Enterococcus faecalis, Mineral trioxide aggregate sealer.

(c) 2019 The Authors. Published by Innovare Academic Sciences Pvt Ltd. This is an open access article under the CC BY license (http://creativecommons. org/licenses/by/4. 0/) DOI: http://dx.doi.org/10.22159/ijap.2019.v11s1.AR178

\section{INTRODUCTION}

Enterococcus faecalis is a facultative anaerobic microbe present in $23-70 \%$ of cases of failed endodontic treatment with periapical lesion [1]. Successful endodontic treatment is achieved by the endodontic triad: Access preparation, cleaning and shaping, and obturation. Since all the microbes in root canals cannot be eliminated by chemomechanical preparation, hermetic obturation with an antimicrobial filler and sealer material is needed to eliminate the remaining microbes $[2,3]$.

Calcium hydroxide $\left(\mathrm{Ca}(\mathrm{OH})_{2}\right)$ sealer, which is biocompatible, has limited antimicrobial activity [4,5]. The mineral trioxide aggregate (MTA) sealer has good adhesion, hydrophilic, biocompatibility, and antimicrobial properties [6]. The MTA sealer contains calcium oxide and releases $\mathrm{Ca}(\mathrm{OH})_{2}$ when it contacts fluid. $\mathrm{Ca}(\mathrm{OH})_{2}$ breaks down into hydroxyl ions and increases the $\mathrm{pH}$ level. This process is repeated over a long time period, making the MTA sealer more advantageous than $\mathrm{Ca}(\mathrm{OH})_{2}$ sealer. In a previous study, E. faecalis was resistant at $\mathrm{pH}$ level of 9.5-10, inhibited at $\mathrm{pH}$ 10.5-11, and died at $\geq 11.5[7-10]$.

This study aimed to analyze the antimicrobial activity of MTA and $\mathrm{Ca}(\mathrm{OH})_{2}$ sealers on E. faecalis immediately, 1 day, and 7 days after the preparation of the sealer. The hypothesis of this study is that the MTA sealer has better antimicrobial activity than the $\mathrm{Ca}(\mathrm{OH})_{2}$ sealer due to the properties described.

\section{METHODS}

This experimental study was performed at the Oral Biology Laboratory in the Faculty of Dentistry, University of Indonesia. The materials used included E. faecalis strain ATCC29212, AnaeroGen Compact 5, MTA sealer Fillapex, $\mathrm{Ca}(\mathrm{OH})_{2}$ Apexit Plus sealer, agar blood, brain heart infusion (BHI) broth, Bacto agar, $\mathrm{NaCl} 0.9 \%$, and 0.5 McFarland standard. The instruments used were beaker glass, Eppendorf tubes, Epis, incubator, colony counter unit, object glass, ballpoint, tangle, and Petri dish.

\section{E. faecalis microbial culture}

Microbial suspension was cultured on brain heart agar plates with BHI broth and was incubated under anaerobic conditions at $37^{\circ} \mathrm{C}$ for $2 \times 24 \mathrm{~h}$. The microbial colony turbidity was adjusted using a 0.5 McFarland standard solution $\left(1 \times 10^{8}\right.$ colony-forming unit $\left.[\mathrm{CFU}] / \mathrm{ml}\right)$.

\section{Sample preparation}

$\mathrm{Ca}(\mathrm{OH})_{2}$ sealer (Apexit Plus) and MTA sealer (MTA Fillapex) were placed homogeneously on object glass under humid conditions at $37^{\circ} \mathrm{C}$ and treated immediately, 1 day, and 7 days after the preparation of the sealer.

\section{Direct contact test}

The sealer was placed on the side of the Epis and, then, $0.01 \mathrm{cc}$ microbial suspension was placed on top immediately, 1 day, or 7 days after the preparation of the sealer. Then, the samples were incubated for $1 \mathrm{~h}$ with $100 \%$ humidity at $37^{\circ} \mathrm{C}$. $240 \mu \mathrm{L} \mathrm{BHI}$ broth was added to each sample, was homogenized, and was diluted 10 -fold. For each sealer, a $10 \mu \mathrm{L}$ solution was inoculated on an agar plate and was incubated at $37^{\circ} \mathrm{C}$ for $24 \mathrm{~h}$. Following the incubation, the CFUs were counted. The number of CFUs for each sealer for each time period was analyzed by a parametric one-way analysis of variance (ANOVA) and post hoc tests. The statistical significance was set at $\mathrm{p}<0.05$.

\section{RESULTS}

Table 1 presents the number of CFUs that formed after direct contact between $E$. faecalis and the sealer immediately, 1 day, and 7 days after the preparation of the sealer. For both the MTA and the $\mathrm{Ca}(\mathrm{OH})_{2}$, the lowest number was observed 1 day after the preparation of the sealer.

One-way ANOVA revealed significant differences between antimicrobial activity of the MTA and $\mathrm{Ca}(\mathrm{OH})_{2}$ across the three time points $(\mathrm{p}<0.05)$. Post hoc tests (Table 2) indicated significant differences between E. faecalis colony numbers for the MTA immediately, 1 day, and 7 days after the preparation of the sealer. The MTA sealer placement 1 day and 7 days after preparation decreased E. faecalis number more than 
Table 1: Average and standard deviation of CFUs formed after direct contact between E. faecalis and the MTA or the Ca $(\mathrm{OH})_{2}$ sealer immediately, 1 day, and 7 days after the preparation of the sealer

\begin{tabular}{lllll}
\hline Test group & $\mathbf{n}$ & Mean \pm SD & \multicolumn{2}{c}{$\mathbf{9 5 \% \text { confidence interval }}$} \\
\cline { 4 - 5 } & & & Minimum & Maximum \\
\hline MTA & & & & \\
$\quad$ Immediately & 16 & $575.40 \pm 187.10$ & 475.74 & 675.14 \\
$\quad$ day & 16 & $230.81 \pm 166.78$ & 141.94 & 319.68 \\
$\quad$ days & 16 & $320.44 \pm 226.75$ & 199.61 & 441.26 \\
Ca (OH) & & & & \\
$\quad$ Immediately & 16 & $766.31 \pm 255.46$ & 630.19 & 902.44 \\
$\quad$ d day & 16 & $405.38 \pm 343.33$ & 222.43 & 588.32 \\
$\quad$ days & 16 & $619.81 \pm 383.91$ & 415.24 & 824.38 \\
\hline
\end{tabular}

E. faecalis: Enterococcus faecalism, MTA: Mineral trioxide aggregate,

CFUs: Colony-forming units, $\mathrm{Ca}(\mathrm{OH})_{2}$ : calcium hydroxide

Table 2: Significance values of $E$. faecalis colony numbers between MTA sealer and Ca $(\mathrm{OH})_{2}$ sealer immediately, 1 day, and 7 days after the preparation of the sealer

\begin{tabular}{lll}
\hline Test group I & Test group II & p value \\
\hline MTA immediately & MTA 1 day & $0.001^{*}$ \\
& MTA 7 days & $0.010^{*}$ \\
& Ca $(\mathrm{OH})_{2}$ immidiate & 0.050 \\
MTA 1 day & MTA 7 days & 0.354 \\
& $\mathrm{Ca}(\mathrm{OH})_{2}$ 1 day & 0.073 \\
MTA 7 days & $\mathrm{Ca}(\mathrm{OH})_{2} 7$ days & $0.003^{*}$ \\
Ca $(\mathrm{OH})_{2}$ immediately & $\mathrm{Ca}(\mathrm{OH})_{2}$ 1 day & $0.000^{*}$ \\
Ca $(\mathrm{OH})_{2} 1$ day & $\mathrm{Ca}(\mathrm{OH})_{2} 7$ days & 0.132 \\
\hline
\end{tabular}

*Post hoc analysis, *significance value $\mathrm{p}<0.05$. E. faecalis: Enterococcus faecalis, MTA: Mineral trioxide aggregate, $\mathrm{Ca}(\mathrm{OH})_{2}$ : calcium hydroxide

immediate placement. The best antimicrobial activity for the MTA occurred 1 day and 7 days after the preparation of the sealer, with no significant difference between the two time points. For $\mathrm{Ca}(\mathrm{OH})_{2}$, placement 1 day after preparation showed a significantly greater decrease than immediate placement or placement 7 days after preparation. 1 day after preparation, the ability of the MTA sealer to decrease E. faecalis colonies was equal to that of the $\mathrm{Ca}(\mathrm{OH})_{2}$ sealer. 7 days after preparation, the MTA sealer had better antimicrobial activity than $\mathrm{Ca}(\mathrm{OH}) 2$

\section{DISCUSSION}

E. faecalis is a pathogenic microbe found in 38\% of failed endodontic treatment cases [11]. This microbe can resist extreme conditions and a lack of oxygen and nutrition and can form a biofilm matrix that inhibits antimicrobial agents $[2,11-13]$.

The $\mathrm{Ca}(\mathrm{OH})_{2}$ sealer is biocompatible and releases hydroxyl ions, creating a basic environment that eliminates microbes. However, the antimicrobial activity is limited because it cannot maintain a high $\mathrm{pH}$ for a long period [14]. The MTA sealer has high biocompatibility and works as a $\mathrm{Ca}(\mathrm{OH})_{2}$ sealer. When it contacts tissue fluid, the MTA releases calcium ions that react with phosphate ions, creating calcium phosphate. Calcium phosphate forms carbonated apatite, which is a layer between the MTA and dentin, similar to hydroxyapatite. This layer hermetically seals the root canal, thereby eliminating remaining microbes. The MTA sealer is composed of calcium oxide which, every time it contacts water, creates $\mathrm{Ca}(\mathrm{OH})_{2}$ that breaks into calcium and hydroxyl ions, thereby maintaining a high $\mathrm{pH}$ in the tissue [15-18].

The $\mathrm{Ca}(\mathrm{OH})_{2}$ antimicrobial activity is achieved by disrupting microbial cytoplasmic membranes through lipid LTA peroxidation of $E$. faecalis cell membranes, resulting in protein denaturation and the inhibition of microbial DNA replication [19].
The antimicrobial activity of MTA sealer 1 day and 7 days after preparation was the best among the MTA sealer group. This is supported by Ustun et al. [20,21] who showed that MTA sealer was not effective on $E$. faecalis $20 \mathrm{~min}$ after the preparation of the sealer but was effective 1 day and 7 days after the preparation of the sealer. The $\mathrm{Ca}(\mathrm{OH})_{2}$ releasing process in MTA occurs every time that there is contact with tissue fluid; therefore, the $\mathrm{pH}$ remained high causing a constant antimicrobial activity until 7 days after the preparation of the sealer [18,22-24]. Fridland showed that MTA can maintain a pH high of 11-12 for up to 78 days [25]. The low antimicrobial activity in MTA sealer immediately after preparation was affected by the initial setting time $(2.27 \pm 0.06 \mathrm{~h})$ and the final setting time $(4.55 \pm 0.05 \mathrm{~h})$. As soon as the sealer was prepared, the setting reaction that formed $\mathrm{Ca}(\mathrm{OH})_{2}$ had not yet occurred [26]. This is supported by a previous study showing that the MTA and the $\mathrm{Ca}(\mathrm{OH})_{2}$, sealer at 1 day had an equal ability to decrease E. faecalis colony. Rather, antimicrobial activity was affected by the $\mathrm{Ca}(\mathrm{OH})_{2}$ formed after setting [27].

The number of $E$. faecalis colonies after contact with the $\mathrm{Ca}(\mathrm{OH})_{2}$ sealer 1 day after preparation was lower than for the immediately after and 7 days after groups. This finding supports that the $\mathrm{Ca}(\mathrm{OH})_{2}$ antimicrobial activity occurred after setting, which took $2 \mathrm{~h} 15 \mathrm{~min}$, and continuously decreased overtime [28]. This pattern is supported by Zhang et al. [29] who showed that $\mathrm{Ca}(\mathrm{OH})_{2}$ could not eliminate microbes in the first $60 \mathrm{~min}$ after the preparation of the sealer and had not yet completed the setting reaction. Slutzky-Goldberg [30] showed that $\mathrm{Ca}(\mathrm{OH})_{2}$, sealer had a short-term antimicrobial effect of 1 day on E. faecalis. The $\mathrm{Ca}(\mathrm{OH})_{2}$ antimicrobial activity depended on hydroxyl ions and was effective if the $\mathrm{pH}$ remained high. However, $\mathrm{Ca}(\mathrm{OH})_{2}$ could not create hydroxyl ions once it had broken down completely. Hence, the $\mathrm{pH}$ decreased overtime, from 12.5 to 9.14. This caused a decrease in $\mathrm{Ca}(\mathrm{OH})_{2}$ antimicrobial activity on E. faecalis, which can resist a $\mathrm{pH}>11.5[11,19]$.

\section{CONCLUSION}

The MTA sealer had better antimicrobial effects than $\mathrm{Ca}(\mathrm{OH})_{2}$ sealer did by direct contact on E. faecalis immediately, 1 day, and 7 days after the preparation of the sealer.

\section{CONFLICTS OF INTEREST}

The authors report no conflicts of interest.

\section{REFERENCES}

1. Kayaoglu G, Ørstavik D. Virulence factors of Enterococcus faecalis: Relationship to endodontic disease. Crit Rev Oral Biol Med 2004; 15:308-20.

2. Johnson WT, Kulild JC. Obturation of the cleaned and shaped root canal system. In: Hargreaves KM, Cohen S, editors. Cohen's Pathways of the Pulp. $10^{\text {th }}$ ed. St Louis: Mosby Elsevier; 2011. p. 349, 359-61.

3. American Association of Endodontics: Endodontics Colleagues for Excellence. Obturation of Root Canal Systems 2009. Available from: http://www.aae.org/uploadedFiles/Publications_and_Research/ Endodontics Colleagues for Excellence Newsletter/fall09ecfe.pdf, tanggal. [Last accessed on 2013 Jul 25].

4. Rawtiya M, Verma K, Singh S, Munuga S, Khan S. MTA-based root canal sealers. J Orofac Res 2013;3:16-21.

5. Bouillaguet S, Wataha JC, Lockwood PE, Galgano C, Golay A, Krejci I, et al. Cytotoxicity and sealing properties of four classes of endodontic sealers evaluated by succinic dehydrogenase activity and confocal laser scanning microscopy. Eur J Oral Sci 2004;112:182-7.

6. Rao A, Rao A, Shenoy R. Mineral trioxide aggregate - A review. J Clin Pediatr Dent 2009;34:1-8.

7. Goel M, Bala S, Sachdeva G, Shweta C. Comparative ecaluation of mta, calcium hydroxide and Portland cement as a root end filling materials: A comprehensive review. Indian J Dent Sci 2011;5:130-3.

8. Harshard PN, Wasim M. Evaluation of the effect of ph in the elimination of Enterococcus faecalis-in vitro study. J Ahmedabad Dent Coll Hosp 2011;2:119-123.

9. Mohammadi Z, Dummer PM. Properties and applications of calcium hydroxide in endodontics and dental traumatology. Int Endod J 2011;44:697-730.

10. Gopikrishna V, Kandaswamy D, Jeyavel RK. Comparative evaluation 
of the antimicrobial efficacy of five endodontic root canal sealers against Enterococcus faecalis and candida albicans. J Conserv Dent 2006;9:2-12.

11. Stuart CH, Schwartz SA, Beeson TJ, Owatz CB. Enterococcus faecalis: Its role in root canal treatment failure and current concepts in retreatment. J Endod 2006;32:93-8.

12. Chai WL, Hamimah H, Cheng SC, Sallam AA, Abdullah M. Susceptibility of Enterococcus faecalis biofilm to antibiotics and calcium hydroxide. J Oral Sci 2007:49:161-6

13. Athanassiadis B, Abbott PV, Walsh LJ. The use of calcium hydroxide, antibiotics and biocides as antimicrobial medicaments in endodontics. Aust Dent J 2007;52:S64-82.

14. Desai S, Chandler N. Calcium hydroxide-based root canal sealers: A review. J Endod 2009;35:475-80

15. Rawtiya M, Verma K, Singh S, Munuga S, Khan S. MTA-based root canal sealers. J Orofac Res 2013;3:16-21.

16. MTA Fillapex Endodontic Sealer. Available from: https://www. clinicalresearchdental.com/marketing/mta $\% 20$ fillapex $\% 20-\% 20$ scientific\%20profile_medium.pdf. [Last accessed on 2013 May 15].

17. Chang SW. Chemical characteristics of mineral trioxide aggregate and its hydration reaction. Restor Dent Endod 2012;37:188-93.

18. Gomes-Filho JE, Moreira JV, Watanabe S, Lodi CS, Cintra LT, Dezan Junior E, et al. Sealability of MTA and calcium hydroxidecontaining sealers. J Appl Oral Sci 2012;20:347-51.

19. Siqueira JF Jr., Lopes HP. Mechanisms of antimicrobial activity of calcium hydroxide: A critical review. Int Endod J 1999;32:361-9.

20. Ustun Y, Sagsen B, Durmaz S, Percin D. In vitro antimicrobial efficiency of different root canal sealers against Enterecoccus faecalis. Eur J Gen Dent 2013;2:134-8.

21. Al-Hezaimi K, Al-Shalan TA, Naghshbandi J, Oglesby S, Simon JH, Rotstein I, et al. Antibacterial effect of two mineral trioxide aggregate
(MTA) preparations against Enterococcus faecalis and Streptococcus sanguis in vitro. J Endod 2006;32:1053-6.

22. Sluyk SR, Moon PC, Hartwell GR. Evaluation of setting properties and retention characteristics of mineral trioxide aggregate when used as a furcation perforation repair material. J Endod 1998;24:768-71.

23. Stowe TJ, Sedgley CM, Stowe B, Fenno JC. The effects of chlorhexidine gluconate $(0.12 \%)$ on the antimicrobial properties of tooth-colored proRoot mineral trioxide aggregate. J Endod 2004;30:429-31.

24. Parirokh M, Torabinejad M. Mineral trioxide aggregate: A comprehensive literature review - part I: Chemical, physical, and antibacterial properties. J Endod 2010;36:16-27.

25. Baik JE, Jang KS, Kang SS, Yun CH, Lee K, Kim BG, et al. Calcium hydroxide inactivates lipoteichoic acid from Enterococcus faecalis through deacylation of the lipid moiety. J Endod 2011;37:191-6.

26. Vitti RP, Prati C, Silva EJ, Sinhoreti MA, Zanchi CH, de Souza e Silva MG, et al. Physical properties of MTA fillapex sealer. J Endod 2013;39:915-8.

27. Weckwerth PH, Siquinelli NB, Weckwerth AC, Vivan RR, Duarte MA. In vitro determination of direct antimicrobial effect of calcium hydroxide associated with different substances against Enterococcus faecalis strains. Dent Press Endod 2011;1:46-51.

28. Sbicego S. Apexit Plus Scientific Documentation. Liechtenstein: Ivoclar Vivadent AG; 2007. Available from: http://www.ivoclarvivadent.com/ zoolu-website/media/document/1207/Apexit+Plus. [Last accessed on 2013 Agu 20].

29. Zhang H, Shen Y, Ruse ND, Haapasalo M. Antibacterial activity of endodontic sealers by modified direct contact test against Enterococcus faecalis. J Endod 2009;35:1051-5.

30. Slutzky-Goldberg I, Slutzky H, Solomonov M, Moshonov J, Weiss EI, Matalon S, et al. Antibacterial properties of four endodontic sealers. J Endod 2008;34:735-8. 